\title{
A Conversation with Caroline Dean
}

\author{
INTERVIEWER: JAN WITKOWSKI \\ Cold Spring Harbor Laboratory
}

\begin{abstract}
Dame Caroline Dean, DBE, FRS is a Group Leader and Royal Society Professor in the
\end{abstract} Department of Cell and Developmental Biology at the John Innes Centre.

Jan Witkowski: Can you give me an overview of your work and how you came to do this?

Dr. Dean: My lab works on how plants know when to flower, so I got into this wonderful world of chromatin and RNA through quite an unintentional route. Many years ago I went back to the U.K., having been a postdoc in the U.S., and decided seasonal timing was really interesting. The place I live in-Norwich-has fairly distinct winters and in spring we have this wonderful bloom. The question is, how is flowering so synchronized?

My lab decided to study the molecular control of flowering, focusing on how plants decide whether to overwinter before flowering, and how they perceive winter. The many genetic routes we used to study these questions led us into the study of one gene. It's a gene that encodes a repressor of flowering. To be able to flower, the plant switches that gene off through a cold-induced Polycomb switching mechanism.

As we dissected this mechanism, we came across a set of antisense transcripts at the repressor locus so we have spent time dissecting how regulatory RNAs affect the chromatin environment of the locus, which affects the transcriptional output, which then affects whether the plants actually need winter and whether they can respond to winter.

Jan Witkowski: And what does this core repressor do?

Dr. Dean: The repressor keeps "off" all the genes in a cell that are required for flowering. Think of it as a brake to flowering: If the protein is expressed, the plant doesn't flower. So, you have to take that away. Winter takes it away. Or you don't make it in the first place, in which case you can flower straight away.

Jan Witkowski: How do the antisense transcripts get turned on? What sensing mechanism does the plant have for perceiving its environment?

Dr. Dean: The antisense transcripts actually completely encompasses the sense transcript. The $5^{\prime}$ end of the antisense starts just upstream of the sense stop site and ends just upstream of the sense start site. The antisense tran- scripts are made constitutively at a low level but are strongly induced by low temperature. We've looked at how they're cold-induced, and it involves a promoter region that aligns with the end of the sense transcript. This promoter is stimulated by cold temperature in a process involving a chromatin structure called an Rloop, where the antisense RNA invades the chromatin. How that is regulated by temperature, we still don't know.

Jan Witkowski: Are there parallels with regulation in other organisms?

Dr. Dean: The parallel that I like to follow is the RNAmediated chromatin silencing mechanism from Rob Martienssen's or Shiv Grewal's work on small-RNA-mediated silencing of centromeric repeats. They also study how a chromatin target is selected, how a certain level of expression is determined and then inherited faithfully through mitosis. The question is how do you copy those histone modifications every generation to actually keep that transcription state epigenetically stable through many generations?

Jan Witkowski: How does this work you are doing relate to vernalization?

Dr. Dean: Vernalization is the cold-induced epigenetic silencing of the repressor gene. Plants perceive the long period of cold winter and slowly silence the repressor gene-it's called FLC [Flowering Locus C] gene-and that is the process of vernalization. We study it in Arabidopsis where we can exploit a molecular genetic approach. Unlike rapid cycling varieties that people normally use in their genetics, we use winter annual types that germinate in autumn and overwinter, which synchronizes their flowering in spring. That's the process of vernalization: the ability to perceive the cold, to silence this gene, and then to maintain that silencing through the subsequent warmth and growth.

Jan Witkowski: Can you remind me what Lysenko was doing? He was trying to get spring wheat flowering in the winter?

(C) 2019 Dean. This article is distributed under the terms of the Creative Commons Attribution-NonCommercial License, which permits reuse and redistribution, except for commercial purposes, provided that the original author and source are credited. 
Dr. Dean: Yes. Many plant species show this vernalization requirement. A lot of people will be familiar with winter- and spring-sown varieties of wheat. Winter varieties need to be sown in autumn, and vernalization occurs during the cold temperatures as they overwinter. It's a slightly different mechanism in wheat, but there's an epigenetic memory of that cold exposure and then you get enhanced seed yield. Vernalization gives enhanced fitness to the plant.

Lysenko imagined that once you had that enhanced yield, it would then be stable through plant generations. That was the mistake, because actually vernalization is reset every generation. Each time the seed is sown it needs to experience the cold to get the benefit for yield. Of course, the farmers in Russia didn't realize this. They didn't revernalize each generation, so they didn't get the yield bonus.

Jan Witkowski: Are plants more difficult to work with? Are animal cells more tractable for doing RNA-related work?

Dr. Dean: No, I think plants are a great system to do analyze functions of noncoding RNAs. Plants are very responsive to their environment so need to have mechanisms to integrate noisy signals and remember previous exposure. Arabidopsis and other model systems-Drosophila, C. elegans - are excellent for mechanistic dissection of complex traits.

For example, forward genetics has been a great way to elucidate the complex regulatory hierarchy controlling flowering time. That would have been much harder starting just from -omics data.

Jan Witkowski: But you do have generation time. It takes longer to work with plants.

Dr. Dean: Arabidopsis cycles in about 6 weeks, so it's not too bad. The Arabidopsis revolution has changed plant biology considerably. It was one of the first eukaryotic genomes to be fully sequenced. We have got knockouts of every gene; we have got natural variants. Arabidopsis thaliana grows from the Arctic Circle down to the equator, so there are tremendous resources to actually use for various questions.

Jan Witkowski: There's always the discussion to what extent model organism represents other organisms. Is Arabidopsis a true representative of plants in general?

Dr. Dean: Absolutely, and not only plant systems. For example, cellular memory mechanisms are very conserved so what we learn about vernalization is relevant for mammalian silencing. You can most easily dissect mechanism in a model system, and then explore the evolutionary variation.

Jan Witkowski: If I could grant you any wish, what would you like to know about what you work on?

Dr. Dean: My big wish would be to understand how epigenetic memory through Polycomb complexes is faithfully inherited through cell division. 


\section{$\$_{\text {CSH\& }}^{\infty}$ Cold Spring Harbor Symposia SYMPOSIA on Quantitative Biology}

\section{A Conversation with Caroline Dean}

Cold Spring Harb Symp Quant Biol published online December 20, 2019

Access the most recent version at doi:10.1101/sqb.2019.84.039024

$\mathbf{P}<\mathbf{P} \quad$ Published online December 20, 2019 in advance of the print journal.

Creative This article is distributed under the terms of the

Commons http://creativecommons.org/licenses/by-nc/4.0/, which permits reuse and

License redistribution, except for commercial purposes, provided that the original author and source are credited.

Email Alerting Receive free email alerts when new articles cite this article - sign up in Service the box at the top right corner of the article or click here.

Advance online articles have been peer reviewed and accepted for publication but have not yet appeared in the paper journal (edited, typeset versions may be posted when available prior to final publication). Advance online articles are citable and establish publication priority; they are indexed by PubMed from initial publication. Citations to Advance online articles must include the digital object identifier (DOIs) and date of initial publication.

To subscribe to Cold Spring Harbor Symposia on Quantitative Biology go to: http://symposium.cshlp.org/subscriptions 